\title{
Review of randomized controlled trials of nutritional supplementation in people living with HIV
}

This article was published in the following Dove Press journal:

Nutrition and Dietary Supplements

8 April 2016

Number of times this article has been viewed

\author{
Alicia Sneij \\ Adriana Campa \\ Marianna K Baum \\ Stempel College of Public Health and \\ Social Work, Florida International \\ University, Modesto Maidique \\ Campus, Miami, FL, USA
}

Background: Nutritional deficiencies are widespread in people living with HIV (PLWH), prior to the antiretroviral treatment (ART). Nutrient deficiencies and other nutrition-related conditions, however, have been identified in patients receiving ART. Trials of nutritional supplementation have been conducted to alleviate these nutritional conditions and improve or reverse nutritionrelated outcomes. This review aims to evaluate the benefits of supplementation, its unintended adverse effects, and the difference in approach and focus, research design, formulations, and outcomes between those randomized clinical trials (RCTs) conducted before and after the initiation of ART.

Methods: An evidence-based systematic review of the literature was conducted using electronic databases and the resources of the Florida International University Research Library. Forty-two RCTs were selected for review, and their design and outcomes were compared and contrasted conceptually and in the form of tables.

Results: Most of the RCTs ( $\mathrm{n}=31$ ) were conducted before the advent of ART, and their aims were delaying disease progression, reversing malnutrition, and improving pregnancy outcomes in women and infants infected with HIV. The RCTs conducted with coadministration of ART were fewer ( $n=11$ ), with relative smaller sample size, of shorter duration, and mainly focused on preventing or ameliorating the nutrition-related conditions generated by the chronic infection, its treatment, and the aging of PLWH.

Conclusion: As ART is becoming more accessible worldwide, and people are living longer with the disease, more longitudinal trials of nutritional interventions with larger sample sizes are needed to study the nutritional consequences and potential treatments for PLWH.

Keywords: HIV, antiretroviral therapy, micronutrients, probiotics, AIDS, randomization, clinical trial

\section{Introduction}

In limited-resource countries, severe malnutrition continues to be a growing problem, and it is frequently superimposed on the ongoing HIV pandemic. ${ }^{1}$ Studies among people living with HIV (PLWH) have found metabolic and nutritional abnormalities, which may be either secondary to the HIV infection or due to primary malnutrition caused by insufficient intake. Nutritional deficiencies, when present, compromise the immune system and facilitate HIV disease progression. ${ }^{2}$ In HIV disease, immunodeficiency and deficits in nutrition interact early in the disease, before antiretroviral treatment (ART) is provided; however, nutritional deficits and its possible consequences have also been observed after the disease is managed with ART. ${ }^{3,4}$ Antiretrovirals are life-saving medications that, although do not cure the disease, control its progression ${ }^{5,6}$ and improve
Correspondence: Adriana Campa Stempel College of Public Health and Social Work, Florida International University, I I 200 Southwest 8 Street Modesto Maidique Campus, AHC-5-328, Miami, FL 33199, USA

Tel + I 305348 287|

Email campaa@fiu.edu
Nutrition and Dietary Supplements 2016:8 21-39

21

Dovepress

http://dx.doi.org/10.2147/NDS.\$74712 (c) (1) (5) 2016 Sneij et al. This work is published and licensed by Dove Medical Press Limited. The full terms of this license are available at https://www.dovepress.com/terms.php cc) and incorporate the Creative Commons Attribution - Non Commercial (unported, v3.0) License (http://creativecommons.org/licenses/by-nd/3.0/). By accessing the work you hereby accept the Terms. Non-commercial uses of the work are permitted without any further permission from Dove Medical Press Limited, provided the work is properly attributed. For permission for commercial use of this work, please see paragraphs 4.2 and 5 of our Terms (https://www.dovepress.com/terms.php). 
nutritional status ${ }^{7,8}$ but generate new nutritional challenges. The nutritional problems observed in patients on ART differ from those seen prior to the provision of treatment; ${ }^{7,9-11}$ therefore, the purpose and formulation of the nutritional supplementation should also change. Different from previous reviews of nutritional supplementation in HIV infection, this review of randomized clinical trials (RCTs) of nutritional supplementation in PLWH for the first time considers the coadministration of ART and divides the review according to whether antiretrovirals were used in the trials.

ART suppresses the HIV virus and helps in the recuperation of the immune function. However, only about one-third of patients who achieve viral control recover protective immunity. Poor recovery of the immune function places these patients at increased risk of morbidity and mortality. ${ }^{12-14}$ Moreover, ART combinations containing some of the early antiretrovirals may increase oxidative stress, mitochondrial injury, and increase the host's needs for antioxidants. ${ }^{15-20}$ Chronic ART has also been associated with gastrointestinal (GI) symptoms that may decrease nutrient absorption and metabolism. $^{21}$

Several reports suggest that micronutrient supplementation may support the immune system before and during the chronic use of $\mathrm{ART}^{22-25}$ and prevent ART-associated mitochondrial damage. ${ }^{26,27}$ Multivitamins and minerals are essential for supporting innate immunity, preventing its decline and promoting a timely reconstitution of the specific immune system. ${ }^{15-18,23,28}$ Most of the RCTs of nutritional supplementation reviewed by this work were performed before the availability of ART and demonstrated the immunostimulatory effects of micronutrients in PLWH (Table 1).

The trials in which nutritional supplements were coadministered with ART are few (Tables 2 and 3), with a limited sample size and duration of supplementation. The lack of emphasis on nutritional supplementation after the advent of ART might be due to expectations that treatment with antiretrovirals would have reversed nutritional and metabolic alterations. The interpretation of the findings of RCTs in which nutritional supplements were coadministered with ART is complex. ART combinations are multiple, and the selection of the combination for a given patient depends on the genetics of the host and virus, the degree of resistance to certain antiretrovirals, and personal and national socioeconomic conditions.

This review highlights the benefits of nutritional supplementation before ART is initiated and the scarcity of sufficiently powered RCTs that evaluate the impact of nutritional supplementation during ART on immune recovery, morbidity, and mortality in PLWH.

\section{Background}

The literature indicates that nutritional deficiencies are widespread in PLWH, which are manifested early in the infection, before clinical symptoms are present, and prior to initiating ART. ${ }^{28-38}$ Although the use of ART has been shown to reduce wasting, the condition is still prevalent among patients receiving ART. ${ }^{10}$ In the era of ART, wasting is more frequently observed in cases with virologic and/or immunological failure, who are living in poor socioeconomic conditions and with high food insecurity. ${ }^{10,39}$ Micronutrient deficiencies have also been observed, even in patients receiving chronic ART. Jones et $\mathrm{a}^{40}$ reported a high prevalence of zinc deficiency in participants on ART, adjusting for parameters of acute-phase reaction.

The continuous struggle of the immune system to control HIV may produce a hypermetabolic state, which is associated with increased caloric expenses, high rates of fat oxidation, ${ }^{41}$ and rapid depletion of essential micronutrients. ${ }^{29}$ Therefore, adequate nutritional intake is critical for PLWH, particularly before initiation of ART, to offset the increased nutritional needs for calories and proteins produced by competition for these nutrients with the virus and the demands placed by a continuously activated immune system. The development of combined ART brought expectations that, once the virus was under control, the immune system would recover, the increased nutritional demands would diminish, and nutritional disturbances would be reversed.

Depletion of memory T-cells in the GI mucosa is the consequence of symptoms of diarrhea and malnutrition caused by HIV, which in turn causes bacterial translocation, which furthers immune activation, inflammation and oxidative stress, contributing to HIV progression. ${ }^{42-44}$ Other GI manifestations observed in the pre-ART era were chronic enteropathy and altered GI integrity. ${ }^{45,46}$

ART, however, has also affected GI integrity; patients receiving ART have complications related to colitis associated with antimicrobial medications, side effects of ART, ${ }^{47}$ and changes in microbiota. ${ }^{48}$ Bacterial translocation produced by altered gut integrity has been linked with failure of immune recovery after initiation of ART. ${ }^{49}$ Therefore, as it has been concluded for other conditions, it is important to consider strategies to improve GI integrity and reduce bacterial translocation by improving the composition of the microbiota through the optimization of probiotic supplementation. ${ }^{50-52}$ 


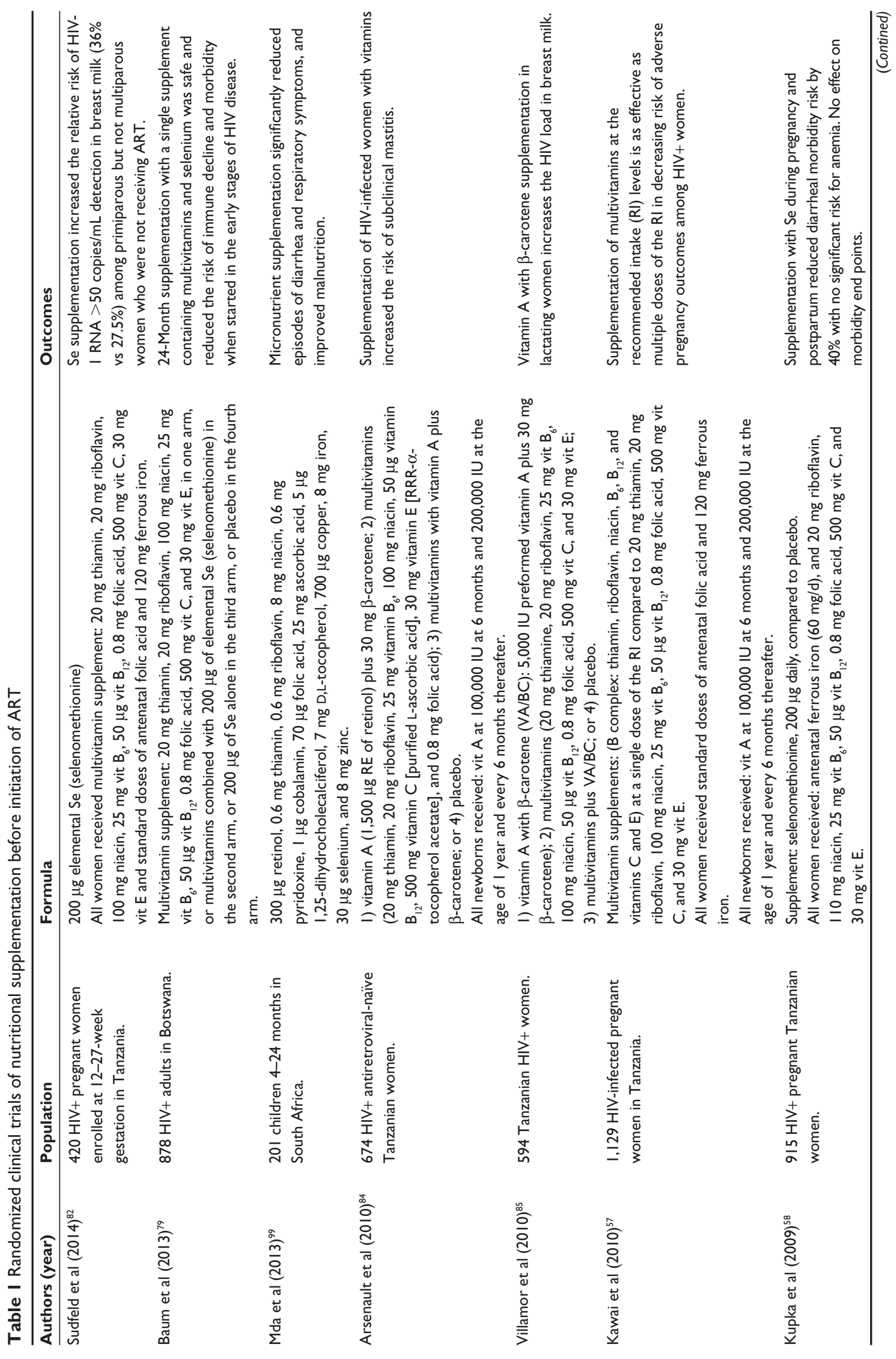



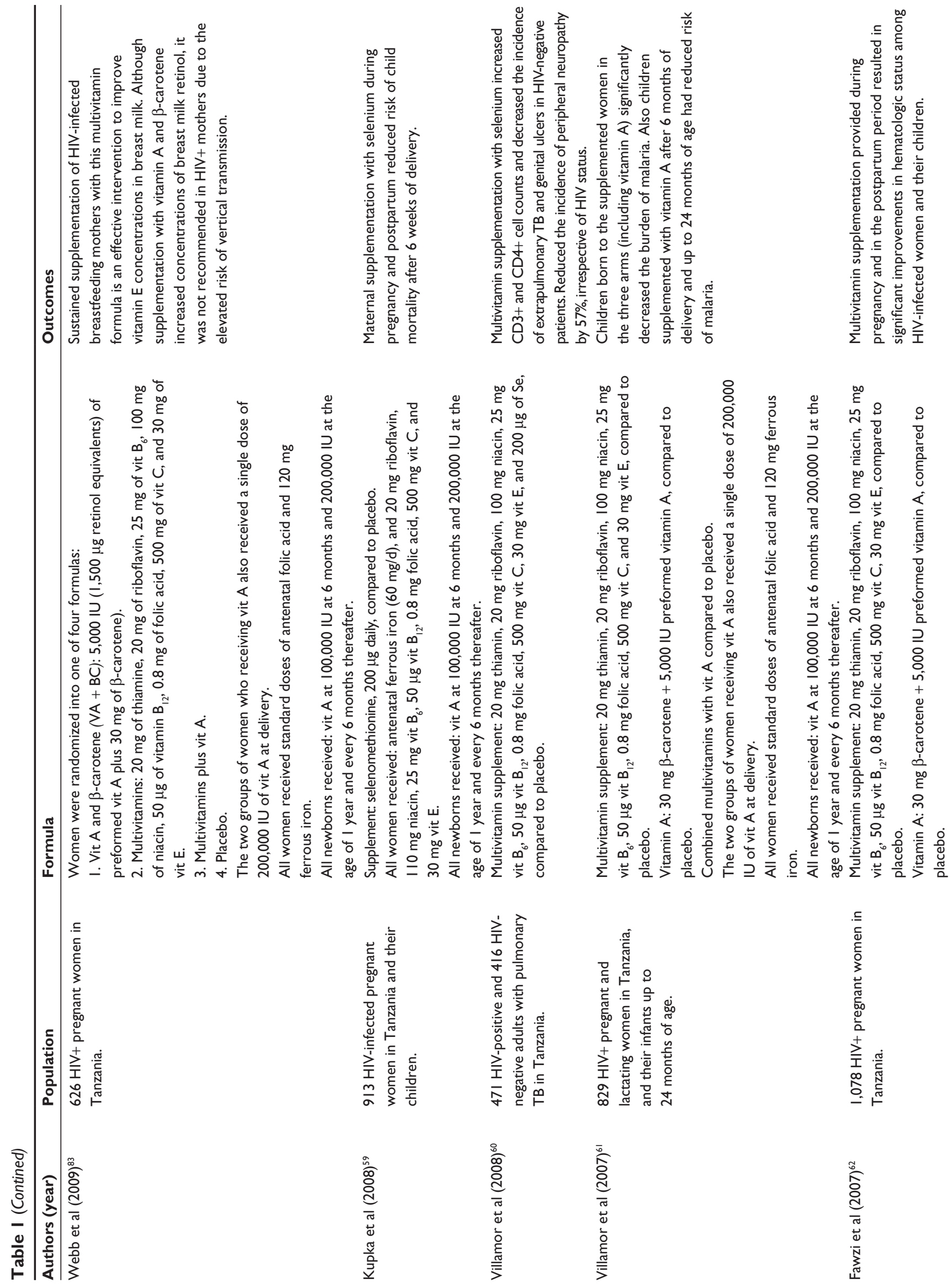

苍 

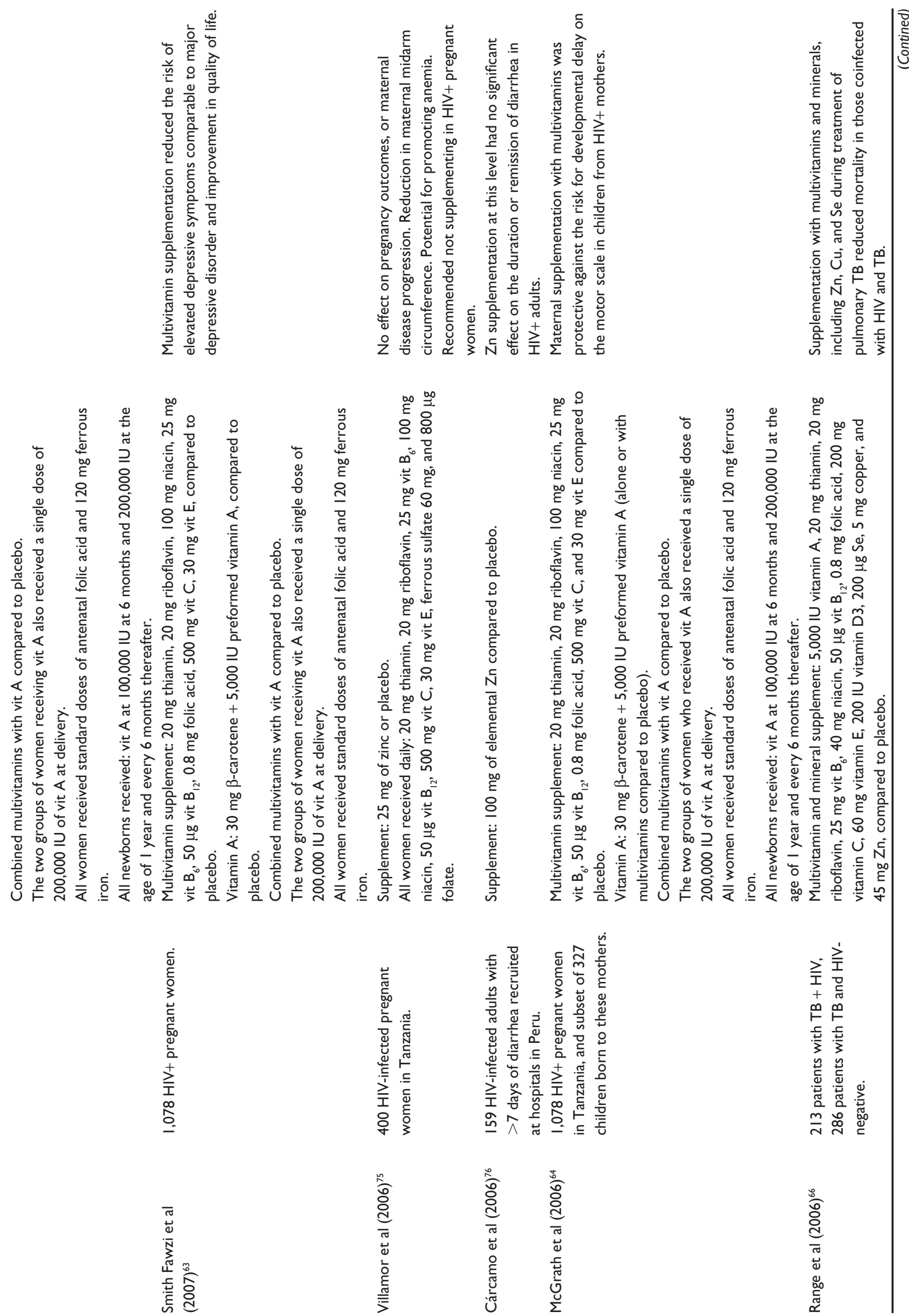

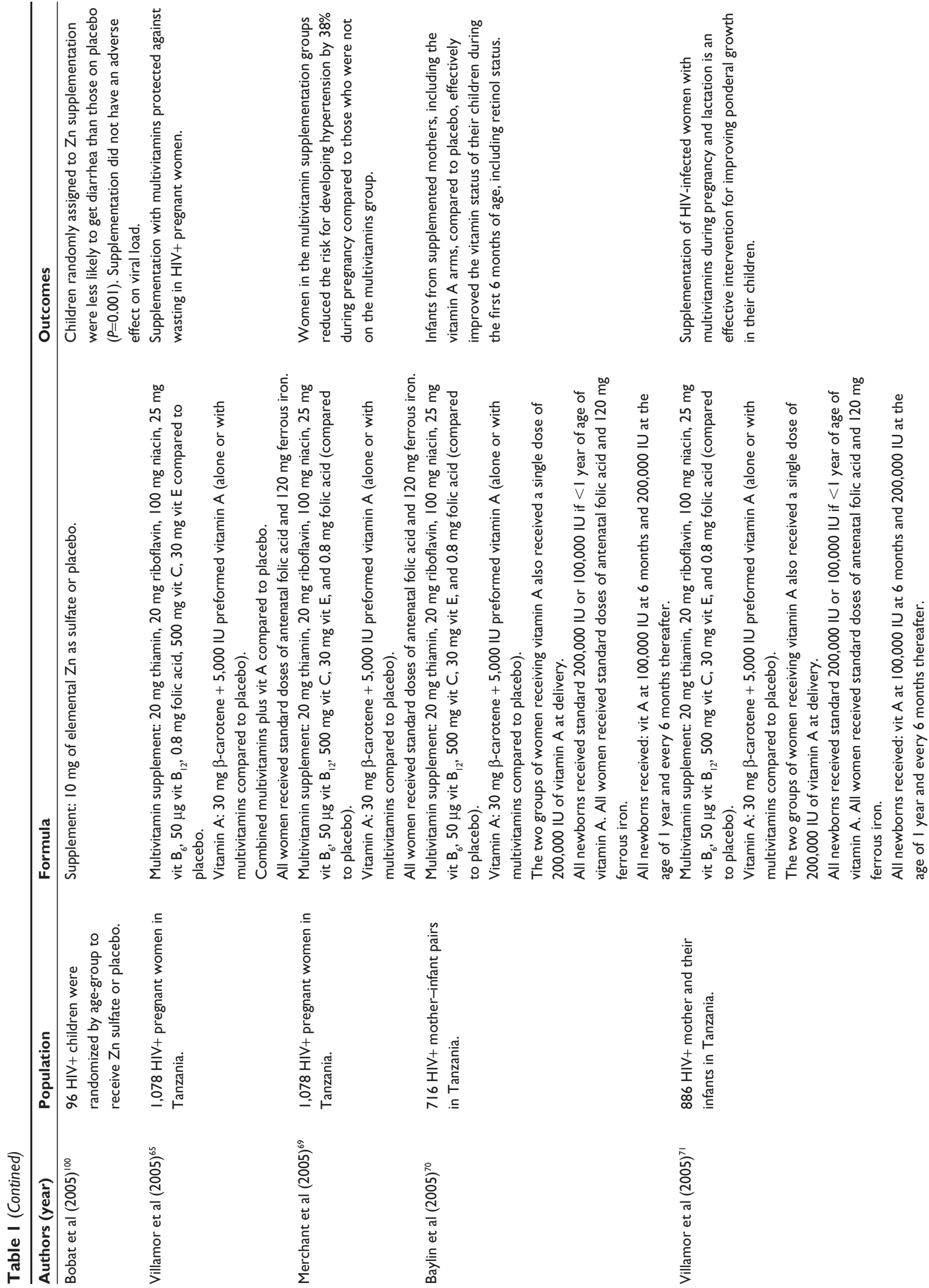

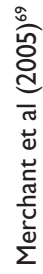

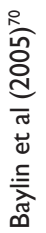

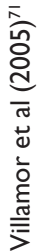



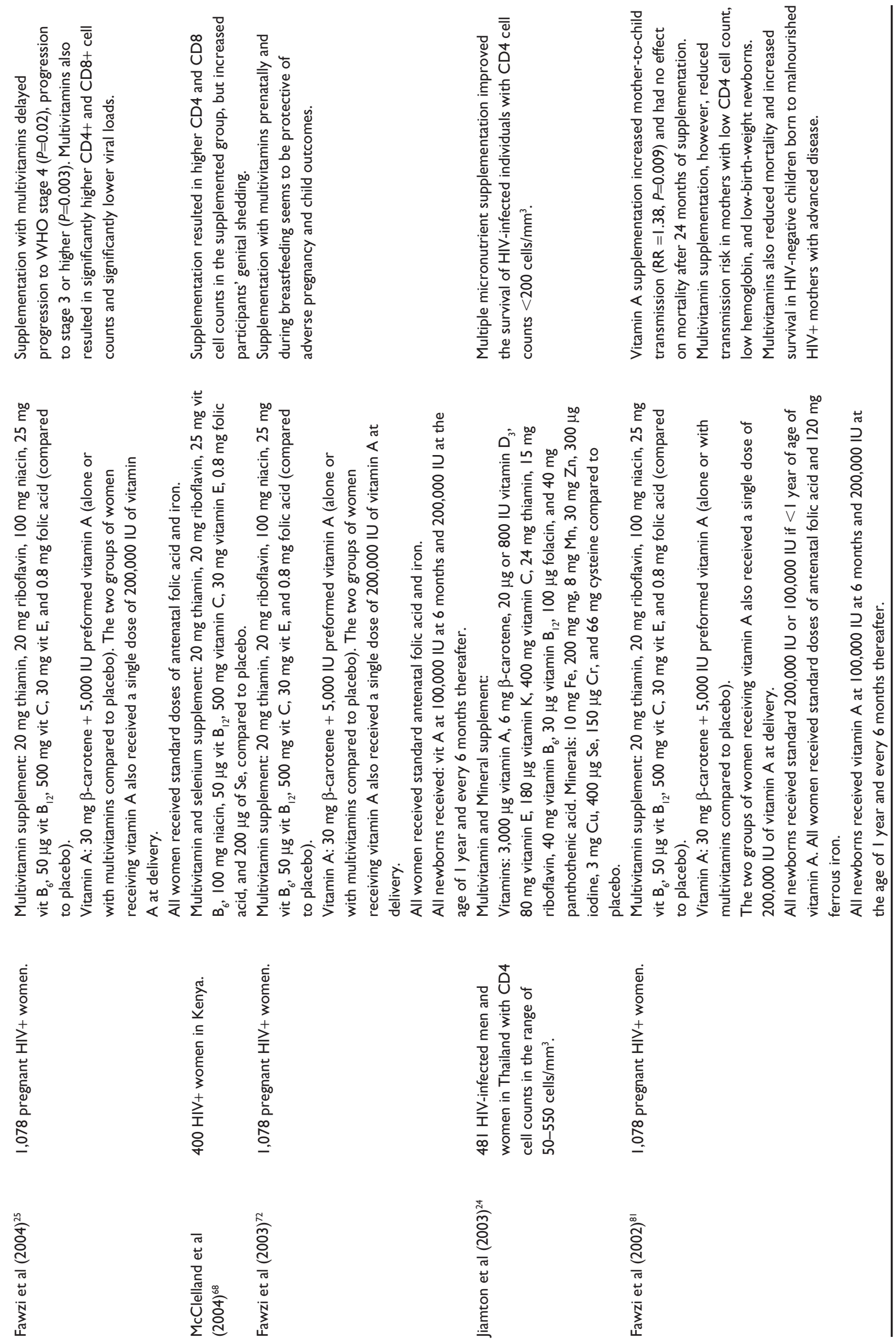

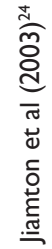

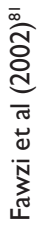




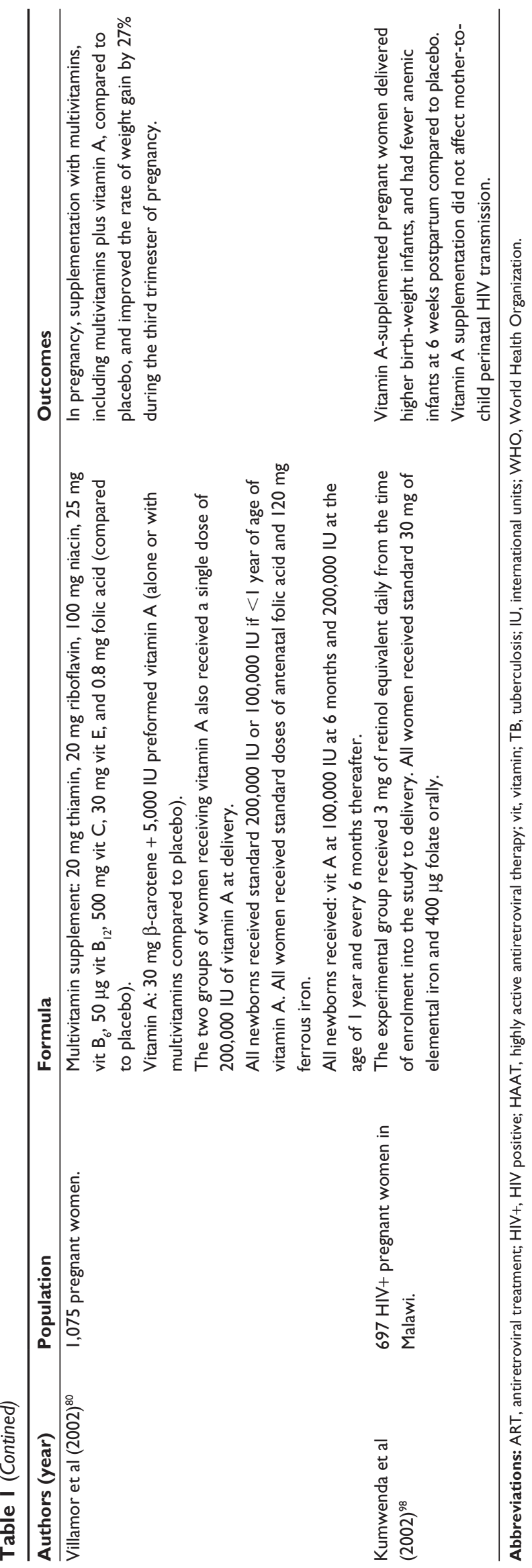

Nutritional interventions need to be individualized to the signs and conditions manifested by the patient, before or coadministered with ART, to preserve the innate immune response, support the recuperation of the immune system, and prevent comorbidities. ${ }^{25}$

Micronutrient deficiencies associated with untreated HIV infection are vitamins A, C, E and D, B vitamins, and antioxidant minerals: selenium and zinc. ${ }^{29,33,34,53-55}$ Although a Cochrane review ${ }^{56}$ found no definite evidence of the role of nutritional supplementation on morbidity, mortality, and HIV disease progression among PLWH, and vitamin A supplementation seems to be beneficial only in children, subsequent reports from RCTs of supplementation have found benefits for both adults and children. ${ }^{23-25,39,57-72}$ ART and nutritional supplementation are not in contradiction, as concluded by another review, ${ }^{73}$ as each of them support the recovery of the immune system by different mechanisms.

This review focuses on evaluating RCTs of supplementation and their outcomes. Most of the RCTs reviewed had limitations, due to differences in length of supplementation, lack of measures of plasma levels of the supplemented micronutrients at baseline, diversity of the nutrients included in the formulas, and the variety in doses.

A number of RCTs reviewed also reported adverse unintentional outcomes of supplementation, such as the association of vitamin A supplementation with increased mother-to-child transmission, ${ }^{25}$ iron with increased mortality, ${ }^{74}$ selenium with vaginal HIV-shedding,${ }^{68}$ zinc with wasting in pregnant women receiving $25 \mathrm{mg}$ of zinc, ${ }^{75}$ and zinc in a dose of $100 \mathrm{mg}$ elemental zinc/d with more frequency of diarrhea in patients with diarrheal condition. ${ }^{76}$

Reports from RCTs that supplemented multivitamins with minerals demonstrated better outcomes than supplementation with a single nutrient. ${ }^{77}$ Supplementation with multiple nutrients compared to a single nutrient on HIV disease outcomes suggests a synergistic interaction among nutrients (Tables 1 and 2), especially with nutritional antioxidants with a high level of metabolic interactions. ${ }^{73}$ Because the efficacy of nutritional supplementation on HIV-disease parameters changes with the use of ART, the trials of supplementation were divided into two categories: trials in ART-naïve populations (Tables 1 and 3) and trials in which supplementation was coadministered with ART (Tables 2 and 3).

Some of the RCT formulas from the reviewed articles contained nonnutritional substances that were not directly 


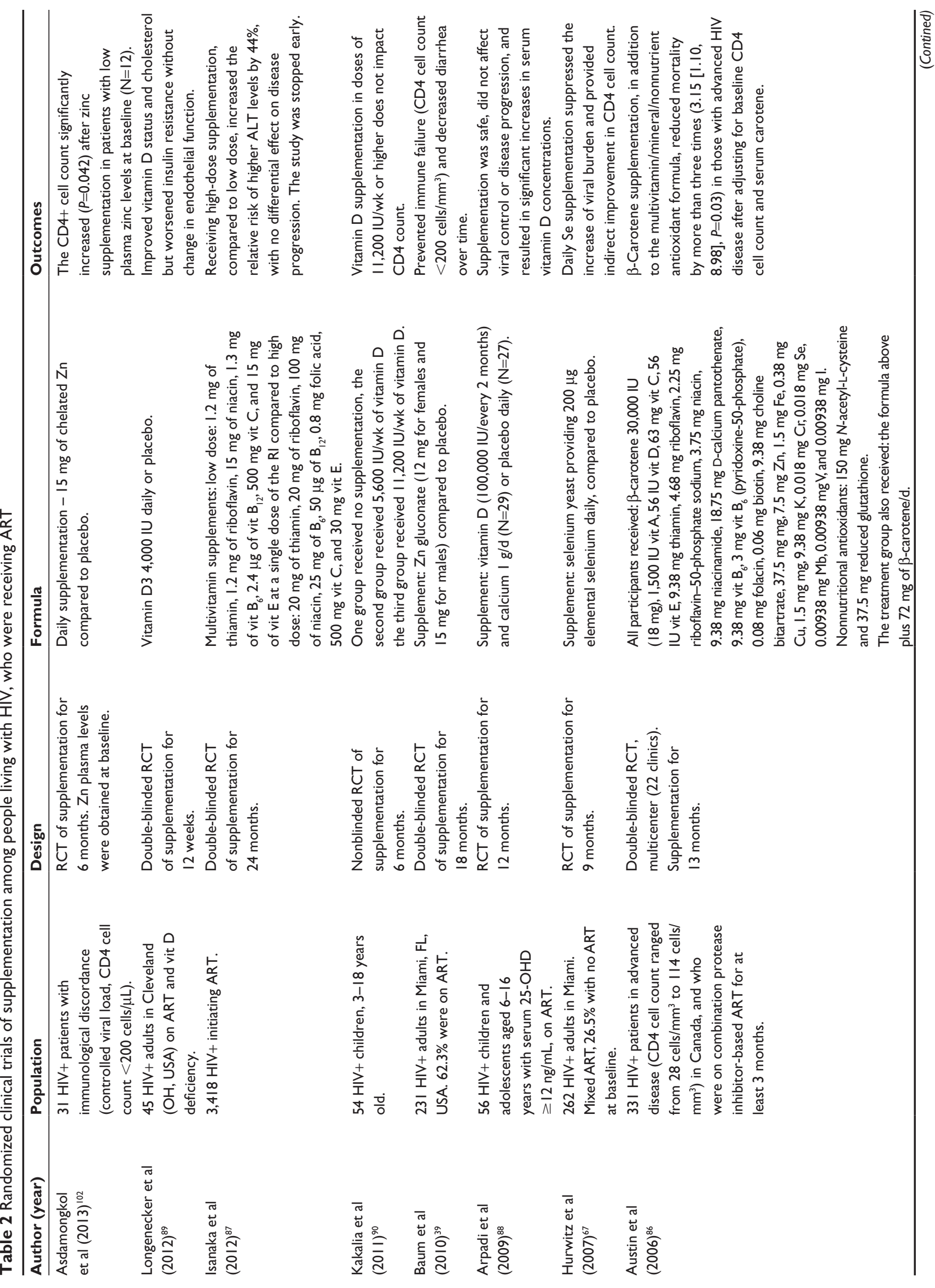




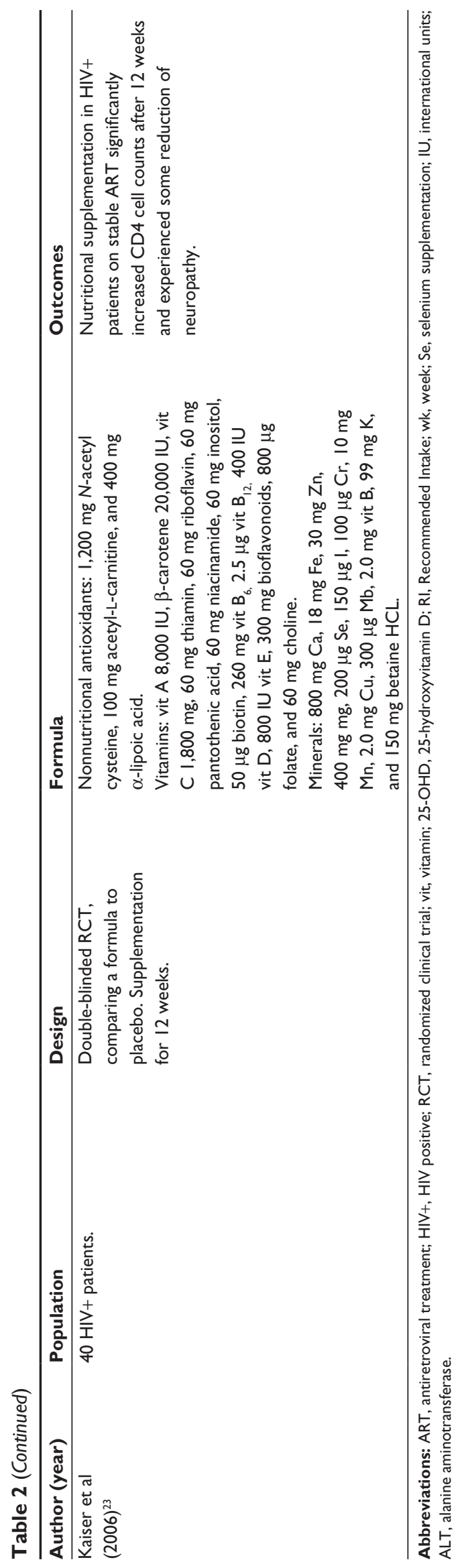

addressed in this review and which are listed as nonnutrients in Tables 1 and 2. The observational research on these nonnutrient substances is scarce, and their evaluation is beyond the focus of this review.

\section{Methods}

This review followed the five steps of the Academy of Dietetics and Nutrition for conducting evidence-based review. ${ }^{78}$ A systematic search of literature was conducted using PubMed and the resources of the Florida International University Library, including the Expanded Academic ASAP, Academic OneFile, Student Resources in Context, and Academic Search Complete to identify high-quality primary reports from RCTs of micronutrient and probiotic supplementation (Figure 1). The RCT design is considered to provide the strongest evidence. ${ }^{78}$ The inclusion criteria for articles reviewed here were primary reports of RCTs in HIV-seropositive patients, $\geq 30$ participants, published in the last 15 years, in English, and with and without coadministration of ART. Articles that did not meet the inclusion criteria were excluded after examination. The keywords used were HIV, nutrition, supplementation, RCT, micronutrients, vitamin, mineral, probiotic, and microbiota in different combinations to foster a wide number of results. The final selection included 42 reports of RCTs of nutritional supplementation in PLWH. These were divided into two categories: those conducted prior to the initiation of ART $(n=31)$ and those in which nutritional supplementation was coadministered with ART $(\mathrm{n}=11)$.

The research questions that guided the review were

- Is nutritional supplementation beneficial in PLWH before and after the initiation of ART?

- How the objectives of the intervention differ before and after receiving ART?

\section{Results}

The majority of the formulas described in the reviewed reports (Tables 1-3) included several levels of $B$ vitamins (thiamin, riboflavin, niacin, $\mathrm{B}_{6}, \mathrm{~B}_{12}$, and folate $)^{23,25,57-66,68-72,79-87}$ as these are important in the energy cycle of the mitochondria and for prevention of mitochondrial oxidative stress. Other antioxidant nutrients such as vitamins $\mathrm{A}, \mathrm{C}$, and $\mathrm{E}$, selenium, and zinc were also included because the immune response to a chronic infection and some ART combinations may aggravate mitochondrial and systematic oxidative stress. ${ }^{15-19}$ Calcium and vitamin $\mathrm{D}$ were included in the formulas provided to cohorts that were coadministered $\mathrm{ART}^{23,88-90}$ because some 
Table 3 Randomized clinical trials of probiotic supplementation

\begin{tabular}{|c|c|c|c|c|}
\hline Authors (year) & Population & Design & Formula & Outcomes \\
\hline \multicolumn{5}{|c|}{ In PLWH (pre-ART) } \\
\hline $\begin{array}{l}\text { Hummelen et al } \\
(20 \mathrm{II})^{103}\end{array}$ & $\begin{array}{l}\text { I I } 2 \text { ART-naïve HIV } \\
\text { patients in Tanzania }\end{array}$ & $\begin{array}{l}\text { Randomized, double- } \\
\text { blind, controlled trial of } \\
\text { micronutrient and yogurt } \\
\text { for } 4 \text { weeks }\end{array}$ & 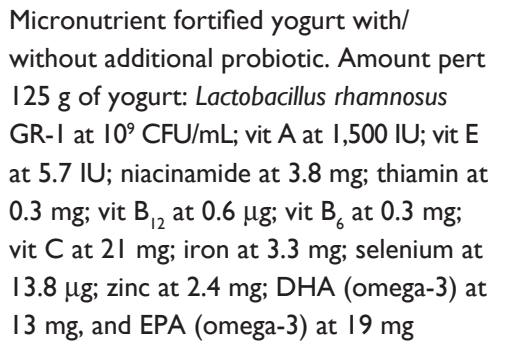 & $\begin{array}{l}\text { Micronutrient fortified } \\
\text { yogurt was well } \\
\text { tolerated by PLWH but } \\
\text { not associated with a } \\
\text { further increase in CD4 } \\
\text { count after } 4 \text { weeks of } \\
\text { supplement }\end{array}$ \\
\hline $\begin{array}{l}\text { Hummelen et al } \\
(2010)^{104}\end{array}$ & $\begin{array}{l}65 \text { HIV+ women with } \\
\text { aberrant microbiota in } \\
\text { Tanzania (Nugent score } \\
4-10 \text { ) }\end{array}$ & $\begin{array}{l}\text { Randomized, double-blind, } \\
\text { placebo-controlled trial } \\
\text { for } 6 \text { months }\end{array}$ & $\begin{array}{l}\text { L. rhamnosus GR-I and Lactobacillus reuteri } \\
\text { RC-I } 4 \text { supplementation compared to } \\
\text { placebo }\end{array}$ & $\begin{array}{l}\text { Supplementation of } \\
\text { probiotic } L \text {. rhamnosus } \\
\text { GR-I and } L \text {. reuteri } \\
\text { RC-I } 4 \text { did not enhance } \\
\text { the cure of bacterial } \\
\text { vaginitis but significantly } \\
\text { increased beneficial } \mathrm{pH} \\
(\mathrm{OR}=3.8, P=0.02)\end{array}$ \\
\hline \multicolumn{5}{|c|}{ In HIV population (post-ART) } \\
\hline $\begin{array}{l}\text { Van Niekerk et al } \\
(20 \mid 4)^{105}\end{array}$ & $\begin{array}{l}74 \text { HIV-exposed and II } 0 \\
\text { nonexposed premature } \\
\text { ( }<34 \text {-week gestation) } \\
\text { infants with a birth } \\
\text { weight of } \geq 500 \text { g and } \\
\leq 1,250 \text { g in Cape Town, } \\
\text { South Africa }\end{array}$ & $\begin{array}{l}\text { Randomized, double-blind, } \\
\text { placebo-controlled trial } \\
\text { supplemented for } 28 \text { days }\end{array}$ & $\begin{array}{l}\text { Study group: breast milk plus a daily } \\
\text { probiotic supplement of } L \text {. rhamnosus } G G \\
\left(0.35 \times 10^{9} \text { colony-forming units [CFU]) and }\right. \\
\text { Bifidobacterium infantis }\left(0.35 \times 10^{9} \mathrm{CFU}\right) \text {; } \\
\text { control group: breast milk plus a placebo } \\
\text { consisting of medium-chain triacylglycerol } \\
(\mathrm{MCT}) \text { oil }\end{array}$ & $\begin{array}{l}\text { Probiotics did not affect } \\
\text { growth outcomes or } \\
\text { incidence of feeding } \\
\text { intolerance in HIV- } \\
\text { exposure infants, but } \\
\text { they had significantly } \\
\text { higher Z-scores for } \\
\text { length and head } \\
\text { circumference than the } \\
\text { unexposed newborns at } \\
\text { the end of the study }\end{array}$ \\
\hline $\begin{array}{l}\text { Villar-García et al } \\
(2015)^{106}\end{array}$ & $\begin{array}{l}44 \text { PLWH with } \\
\text { controlled viral load } \\
<20 \text { copies } / \mathrm{mL}\end{array}$ & $\begin{array}{l}\text { Double-blind, randomized, } \\
\text { placebo-controlled trial }\end{array}$ & $\begin{array}{l}\text { Oral supplementation with probiotics } \\
\text { (Saccharomyces boulardii) or placebo for } \\
\text { I } 2 \text { weeks }\end{array}$ & $\begin{array}{l}\text { S. boulardii treatment } \\
\text { decreased microbial } \\
\text { translocation (LBP) } \\
\text { and inflammation (IL-6) } \\
\text { in HIV-I-infected } \\
\text { patients with long-term } \\
\text { virologic suppression }\end{array}$ \\
\hline
\end{tabular}

Abbreviations: PLWH, people living with HIV; ART, antiretroviral treatment; vit, vitamin; HIV+, HIV positive; OR, odds ratio; LBP, lipopolysaccharide-binding protein; IL-6, interleukin 6; EPA, eicosapentaenoic omega-3 fatty acid; DHA, decosahexaenoic omega-3 fatty acid.

of the treatment combinations, and HIV itself, seem to expose PLWH to bone mass losses. ${ }^{91-96}$ These nutrients were supplemented either at the Recommended Dietary Allowance (RDA) levels ${ }^{97}$ or at several times the RDA values. Summarizing the conclusions is difficult because of the various supplements provided in each trial and the lack of dose-response studies, but most outcomes of the studies that included these micronutrients showed that they were effective in delaying HIV disease progression and safe in ART-naïve populations (Table 1) and after ART initiation when given at nutritional doses (one RDA or under Tolerable Upper Intake Levels) (Table 2). Table 3 describes the trials that included probiotics in their formula.

\section{RCTs of micronutrients in ART-naïve PLWH}

Of the 29 RCTs reviewed in Table 1, 15 reports are from a longitudinal RCT of supplementation conducted in Tanzania, which included 1,078 HIV-infected, ART-naive pregnant women who were followed for a median of 71 months. These pregnant women received $30 \mathrm{mg} \beta$-carotene $+5,000$ IU preformed vitamin A alone, or a multivitamin with $B$ vitamins and vitamins $\mathrm{C}$ and $\mathrm{E}$ alone, or a combination of both, or placebo in a $2 \times 2$ factorial design. In this trial, their newborns were followed for 18-24 months and supplemented with standard 100,000 IU of vitamin A at 6 months and 200,000 IU at 1 year of age and every 6 months thereafter. $^{25,61-65,69-72,80,81,84,85}$ 
The majority of the 15 articles reported benefits such as a reduction in the risk of vertical transmission with multivitamin supplementation, but not with vitamin A, in mothers with a low CD4 cell count, low hemoglobin and low-birth-weight newborns, and that multivitamin supplementation increased the survival of HIV-negative newborns of malnourished mothers with advanced HIV disease. ${ }^{81}$ Multivitamins alone or with vitamin A improved maternal weight gain during the third trimester of pregnancy. ${ }^{80}$ Multivitamins during pregnancy and breastfeeding reduced adverse pregnancy and child outcomes, ${ }^{72}$ including improving newborns' ponderal weight $^{71}$ and vitamin E status, ${ }^{83}$ protecting infants against motor developmental delays, ${ }^{64}$ reducing maternal wasting, ${ }^{65}$ hypertension, ${ }^{69}$ symptoms of depression, improving women's quality of life, ${ }^{63}$ delaying HIV disease progression during pregnancy, ${ }^{25}$ and improving hematological outcomes in both mothers and infants. Supplementation with vitamin A during pregnancy improved the vitamin A status of infants. ${ }^{70}$ The three supplementation arms, including those with vitamin A, decreased the burden of malaria in this cohort. ${ }^{61}$ Other reports from this trial, however, also described adverse effects, such as increased vertical transmission and increased viral load in breast milk with vitamin A supplementation, without reduction in mortality, ${ }^{81,83-85}$ and risk of developing subclinical mastitis with multivitamins. ${ }^{84}$ In contrast, Kumwenda et $\mathrm{al}^{98}$ randomized a cohort of 697 pregnant women in Malawi to receive $3 \mathrm{mg}$ daily of retinol or placebo, in addition to the standard iron and folate supplementation during pregnancy, and concluded that supplementation during pregnancy and postpartum had beneficial effects on newborns' birth weight and prevention of anemia, without changing the rate of mother-to-child transmission.

Baum et $\mathrm{al}^{79}$ supplemented 878 PLWH in Botswana with a multivitamin formula (a B complex with vitamins $\mathrm{C}$ and $\mathrm{E}$ based on that used by Fawzi et $\mathrm{al}^{25}$ ) in a double-blinded RCT with a $2 \times 2$ factorial design. The participants were randomized to selenium ( $200 \mu \mathrm{g}$ of elemental selenium) alone in the first arm of the study, or to multivitamins alone in the second arm, or multivitamins and selenium in combination in the third arm, compared to placebo. The participants were followed for 24 months, and the end points were CD4 cell count $<250$ cells $/ \mu \mathrm{L}$, AIDS-defining conditions, and combinations of both end points as a parameter of HIV disease progression. The supplementation of multivitamin and

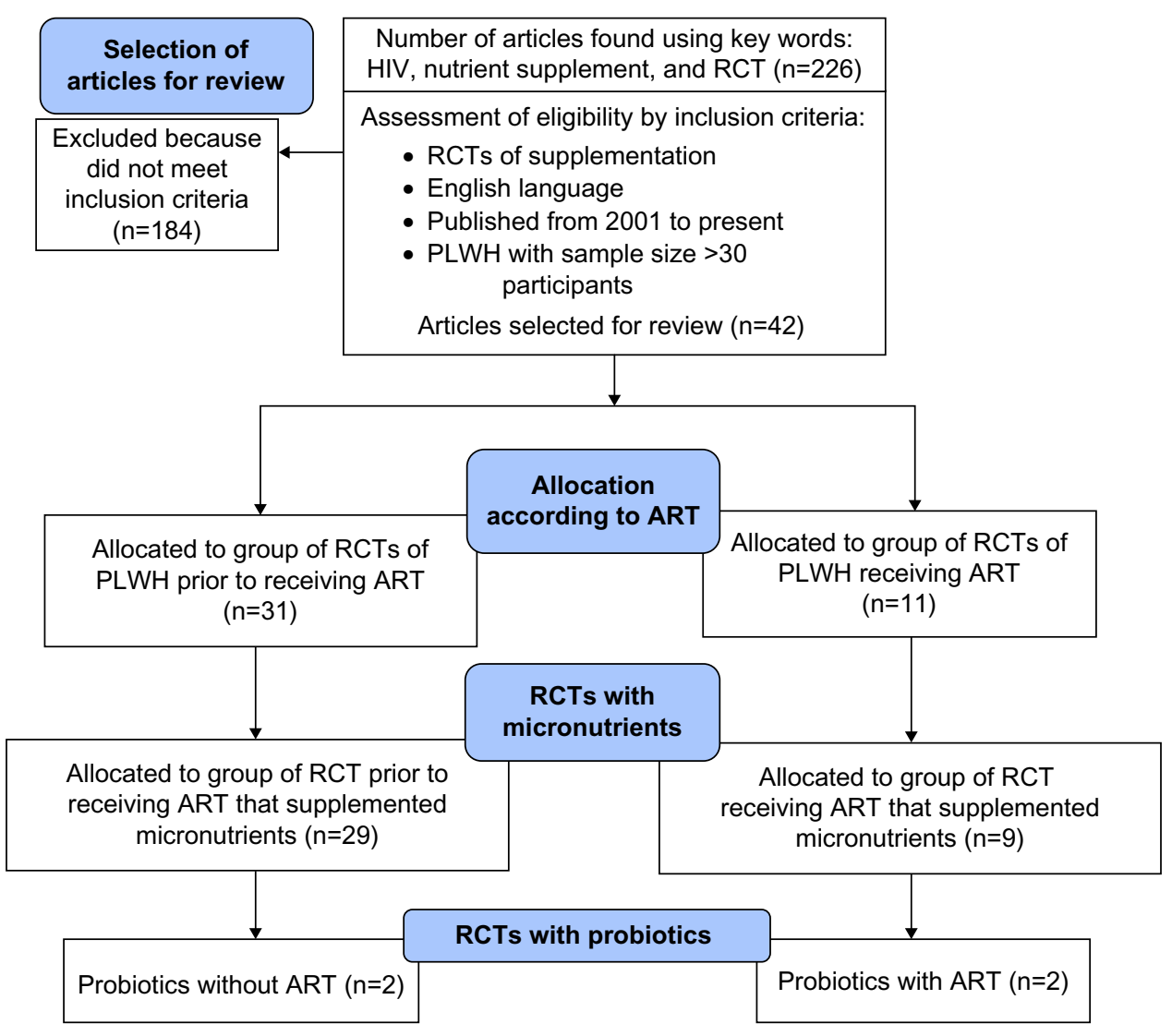

Figure I Consort flow diagram.

Abbreviations: RCT, randomized clinical trial; PLWH, people living with HIV; ART, antiretroviral treatment. 
selenium was safe and reduced the risk of immune decline and morbidity (Table 1). These findings were consistent with those of Jiamton et $\mathrm{al}^{24}$ who reported that supplementation with a complex formula with micronutrients and cysteine improved the survival of persons with advanced HIV disease $(<200$ cells $/ \mu \mathrm{L})$.

Sudfeld et al, ${ }^{82}$ using the multivitamin formula previously described by Fawzi et $\mathrm{al}^{25}$ and Baum et $\mathrm{al}^{79}$ (B complex with vitamins $\mathrm{C}$ and $\mathrm{E}$ ), compared the multivitamin arm with an experimental arm with multivitamins plus $200 \mu \mathrm{g}$ of selenium, in a cohort of 420 pregnant women enrolled at 12-27week gestation and followed until 6 months postpartum. The authors found that in primiparous women, but not in multiparous, the addition of selenium increased the relative risk of HIV-RNA shedding in breast milk.

In a cohort of 915 HIV-positive pregnant women, who were supplemented with multivitamins and selenium in a design similar to that of Sudfeld et al, ${ }^{82}$ Kupka et $\mathrm{al}^{58}$ found that those who were supplemented with selenium had $40 \%$ fewer episodes of diarrhea without increased risk of anemia. In another report from this trial, ${ }^{59}$ the investigators reported a reduced risk of mortality at 6 weeks after birth in children born to women supplemented with selenium and multivitamins. McClelland et $\mathrm{al}^{68}$ also supplemented a similar formula to HIV-positive women in Kenya, and they found improvement in immune measures in those receiving the multivitamin with selenium formula (CD4 cell count +23 cells $/ \mu \mathrm{L}, P=0.03$; and CD 8 cell counts +74 cells $/ \mu \mathrm{L}, P=0.005$ ) compared to placebo; however, they also reported an increase in HIV genital shedding among women receiving the formula.

The same formula of multivitamins with $\mathrm{B}$ vitamins and vitamin $\mathrm{C}$ and $\mathrm{E}^{25,79}$ was also combined with $25 \mathrm{mg}$ of zinc, which is only slightly higher than the RDA recommendation ( $8 \mathrm{mg}$ of zinc for women and $11 \mathrm{mg}$ for men) and compared to placebo. ${ }^{75}$ The experimental formula did not affect pregnancy outcomes or HIV disease progression. Villamor et $\mathrm{al}^{75}$ also reported reduction in maternal midarm circumference, which suggested losses in fat or muscle mass in pregnant women receiving zinc with the multivitamin formula. Mda et $\mathrm{al}^{99}$ randomized 201 children aged 4-24 months into a micronutrient formula appropriate for age or placebo for 6 months, and reported that those randomized into the micronutrient formula significantly reduced episodes of diarrhea, respiratory symptoms, and improved nutritional status.

Bobat et al ${ }^{100}$ randomized 96 children with HIV disease to receive $10 \mathrm{mg}$ of elemental zinc or placebo. The children who received the zinc dose were less likely to get diarrhea and did not experience an increase in their viral load. In comparison, Cárcamo et $\mathrm{al}^{76}$ supplemented 159 adults with HIV with a high dose of zinc (100 mg of elemental zinc) during episodes of diarrhea and did not find an effect on the duration or remission of diarrhea. The comparison of these two studies suggest that zinc supplementation, at lower doses and as prevention, is more effective than during episodes of diarrhea at a very high dose.

In an attempt to clarify the differential effects between high and nutritional doses of multivitamin supplementation, Kawai et $\mathrm{al}^{57}$ compared a multivitamin formula that offered $\mathrm{B}$ vitamins and vitamins $\mathrm{C}$ and $\mathrm{E}$ at the Recommended Intake levels with the $\mathrm{B}$ vitamins and vitamins $\mathrm{C}$ and $\mathrm{E}$ used in higher doses in the aforementioned trials. No differences in adverse pregnancy outcomes were found between the two arms of the study.

In resource-limited countries, tuberculosis (TB) is a significant cause of mortality in PLWH without ART. PLWH who receive isoniazid medication, either as prevention or treatment of TB, may need supplementation with vitamin $\mathrm{B}_{6}$. Receiving lower doses of isoniazid to prevent TB, or in high doses to treat it, may stir symptoms of neuropathy, because the medication blocks the absorption and metabolism of vitamin $\mathrm{B}_{6}$. Supplementation with vitamin $\mathrm{B}_{6}$ was found effective to prevent the symptoms of neuropathy associated with treatment. ${ }^{101}$ Villamor et $\mathrm{al}^{60}$ conducted an RCT of multivitamins with $\mathrm{B}_{6}$ and selenium compared to placebo among a cohort of 887 participants with pulmonary TB that included $471 \mathrm{HIV} / \mathrm{TB}-\mathrm{coinfected} \mathrm{people.} \mathrm{The} \mathrm{authors} \mathrm{reported} \mathrm{a} \mathrm{reduc-}$ tion in peripheral neuropathy by $57 \%$ in TB patients with and without HIV, which is consistent with Kaiser et $\mathrm{al}^{23}$ (Table 2), who supplemented 40 PLWH receiving ART with a complex formula containing $260 \mathrm{mg}$ of $\mathrm{B}_{6}$ and reported improvement in neuropathy in patients on a stable ART combination associated with this condition.

\section{RCTs of micronutrients in PLWH receiving ART}

Two-thirds of the studies described in Table 2, after the initiation of ART, used single nutrients such as zinc, selenium, calcium, and vitamin $\mathrm{D}$, which have been recognized to be deficient after initiation of ART. ${ }^{39,67,88,90,102}$ However, the articles led by Isanaka et al ${ }^{87}$ Austin et al ${ }^{86}$ and Kaiser et $\mathrm{al}^{23}$ reported the use of multiple combinations of multivitamins.

Isanaka et a ${ }^{87}$ compared a low dose to a high dose of the same formula of multivitamins supplemented to ARTnaive patients in Africa ${ }^{25,79}$ and concluded that the high dose 
increased liver transaminases without having a significantly different effect on HIV disease progression. Austin et $\mathrm{al}^{86}$ compared a complex formula with multivitamins, minerals, and nonnutritional antioxidants with the same complex formula with an added higher dose of vitamin A and supplemented for 13 months. This was a multisite RCT in PLWH in advanced disease stage, receiving an ART combination containing protease inhibitors for at least 3 months. All participants received multivitamins and nonnutritional antioxidants as shown in Table 2. The investigators reported a reduced rate of mortality (odds ratio $=3.15, P=0.03$ ) in the group that received $120,000 \mathrm{IU}$ (72 mg) of $\beta$-carotene compared to those who only received the standard formula, after controlling for serum carotene and CD4 cell count at baseline. ${ }^{86}$

Kaiser et $\mathrm{al}^{23}$ conducted a clinical trial of PLWH on stable ART using a complex formula with multivitamins, minerals, and nonnutritional antioxidants compared to placebo for 12 weeks. The investigators found that, compared to placebo, those who received the formula showed a significant increase in CD4 cell counts, with some reduction in neuropathy.

Two of the RCTs of supplementation addressed zinc deficiency in PLWH on ART. In a report from an RCT of zinc supplementation for 6 months, Asdamongkol et al ${ }^{102}$ randomized into zinc or placebo supplementation a group of 31 PLWH with immunological discordance (achieving controlled viral load without increasing CD4 cell count $>200$ cells $/ \mu \mathrm{L}$ ) and found that CD4 cell counts significantly increased in patients who started the study with low plasma levels of zinc. These findings agreed with those of a much larger study by Baum et $\mathrm{al}^{39}$ of 231 adults living with HIV, who used illicit drugs, and were zinc deficient at randomization. The participants received either zinc at the level of $12 \mathrm{mg}$ of elemental zinc for women or $15 \mathrm{mg}$ for men or placebo for 18 months. Zinc supplementation prevented immune failure and decreased episodes of diarrhea.

As vitamin D deficiency has been identified as one of the side effects of long-term antiretroviral use, three of the reports of micronutrient supplementation after ART focused on vitamin D supplementation alone or with calcium. ${ }^{88-90}$ Arpadi et $\mathrm{al}^{88}$ randomized 56 children living with HIV and receiving ART into 100,000 IU of vitamin D every 2 months and $1 \mathrm{~g}$ of calcium daily or placebo during 1 year; the investigators concluded that the intervention did not significantly affect viral control or HIV disease progression, but serum vitamin D significantly increased in those supplemented.

Longenecker et $\mathrm{al}^{89}$ investigated the effects of supplementation with vitamin $\mathrm{D}$ on the endothelial function in PLWH. The study was an RCT that included 45 HIV patients on ART therapy. Participants were randomized into the intervention group, which received 4,000 IU vitamin $\mathrm{D}_{3}$, or into the placebo group and followed for 12 weeks. There was no difference in flow-mediated brachial artery dilation between the two groups $(P=0.748)$. Serum vitamin $\mathrm{D}$ levels significantly increased in the intervention group $(P=0.003)$ and total and non-HDL cholesterol were reduced. Interestingly, vitamin D supplementation was also associated with increased insulin resistance. Further investigation on this relationship is warranted.

Kakalia et $\mathrm{al}^{90}$ also evaluated the effect of vitamin D supplementation on CD4 cell count in 54 children living with HIV, who were randomized into three groups: $800 \mathrm{IU}$ of vitamin $\mathrm{D} / \mathrm{d}, 1,600$ IU of vitamin $\mathrm{D} / \mathrm{d}$, or no supplementation. Serum vitamin D levels significantly increased in the $800 \mathrm{IU} / \mathrm{d}(P=0.0002)$ and $1,600 \mathrm{IU} / \mathrm{d}(P<0.001)$ supplementation groups compared with control. Although vitamin D supplementation increased serum levels, CD4 cell count did not increase. The investigators also concluded that for maintaining adequate vitamin D levels in HIV-infected children, intakes of $\sim 1,600 \mathrm{IU} / \mathrm{d}$ may be required. More longitudinal research is needed to identify potential risk factors for changes in bone mineral density in PLWH receiving specific ART combinations and develop effective medical and nutritional interventions.

\section{RCTs of probiotic supplementation in PLWH}

There have been very few trials of supplementation with probiotics before initiation ${ }^{103,104}$ or concomitant with ART $^{105,106}$ in PLWH (Table 3). The majority of these trials were limited by small sample size, short duration of supplementation and one was combined with micronutrient supplementation. ${ }^{105}$ Hummelen et al ${ }^{103,104}$ in two reports of RCTs conducted in ART-naive patients in Tanzania supplemented Lactobacillus rhamnosus GR-1. In the 2011 article, 112 participants received yogurt in combination with a multivitamin/mineral formula with omega-3 fatty acids, and the experimental group also received L. rhamnosus GR-1 at $10^{9} \mathrm{CFU} / \mathrm{mL}$. The investigators found that the fortified yogurt was well tolerated but did not significantly increase CD4 cell count. The main weakness of this study was that supplementation only occurred for 4 weeks, probably a very short time to observe long-term outcomes. A longer trial of supplementation of probiotics for 6 months by these investigators in Tanzania ${ }^{106}$ found that supplementation with L. rhamnosus GR-1 and L. reuteri $\mathrm{RC}-14$ did not seem to have an effect on bacterial vaginitis but changed the vaginal $\mathrm{pH}$ in a beneficial manner that may prevent the condition. 


\section{Discussion}

A Cochrane review that combined the results from the trials of vitamin A supplementation among pregnant women living with HIV determined that supplementation with vitamin A did not reduce or prevent mother-to-child HIV-1 transmission. ${ }^{107}$ However, other investigators have confirmed benefits in other pregnancy outcomes such as improved birth weight, and lower rates of infant morbidity and mortality. ${ }^{72,73} \mathrm{~A}$ review by Mehta and Fawzi, ${ }^{55}$ which concurred with a 2005 Cochrane review, ${ }^{57}$ reported that vitamin A supplementation should be recommended, because it was beneficial in reducing all-cause mortality and morbidity in infants and children infected with HIV. In adults, vitamin A supplementation in excess of the RDA is not recommended due to its adverse effects on motherto-child transmission, increased HIV breast milk shedding and lack of effect on HIV disease progression.

The majority of studies in PLWH in Table 1, who were ART-naive, used formulas of multivitamins in factorial designs compared to single nutrients or to a combination of multivitamins plus the specific single nutrients or placebo. In contrast, most of the studies after the initiation of ART used single nutrients such as zinc, selenium, calcium and vitamin $\mathrm{D}$, which have been recognized to be deficient after initiation of ART. ${ }^{39,67,88-90,102,105,106}$ The report from Isanaka et $\mathrm{al}^{87}$ suggests that supplementation with multivitamin at the RDA level is still safe in coadministration with ART, but high doses of vitamins should be avoided.

Another study assessed the effect of vitamin supplements on HIV shedding in breast milk in HIV-infected lactating women. Tanzanian lactating women $(n=594)$ were randomized into four groups: placebo, multivitamin, vitamin A and $\beta$-carotene, multivitamin with vitamin A plus $\beta$-carotene. They found that mothers taking vitamin $A$ and $\beta$-carotene had higher detectable viral load than mothers not receiving vitamin A. They concluded that supplementing HIV-infected lactating mothers with vitamin $A$ and $\beta$-carotene increases the HIV viral load in the breast milk and, therefore, increases the risk of mother-to-child transmission. ${ }^{85}$

The benefit of using formulas that contain multiple nutrients is that vitamins and minerals work in conjunction with each other. Providing multiple micronutrients could influence several mechanisms simultaneously, and the effect, instead of being simply additive, becomes synergistic. One of the main limitations of these trials of multiple supplementation is that it is not possible to know which of the vitamins and minerals had more activity, which is important information to optimize formulas.

Recent studies suggest that microbial translocation is a source of immune activation even in PLWH with a suppressed HIV viral load. ${ }^{108,109}$ Elevated plasma levels of endotoxins, which are lipopolysaccharides derived from the cell walls of gram-negative bacteria and a marker of microbial translocation, are produced due to a defective intestinal barrier and dysfunctional macrophage phagocytic clearance of microbial products. ${ }^{110,111}$ The microbial products trigger monocyte/macrophage activation that induces production of proinflammatory cytokines and soluble CD14 (sCD14). ${ }^{42}$ Depletion of CD4+ Th17 cells in the GI wall, early in HIV infection, reduces immunoprotection. ${ }^{112-115}$ The depletion also disrupts the microbiota of the patient, which may lead to greater dominance of potential pathogens, lower levels of lactobacillus species, and increases mucosal inflammation. ${ }^{116}$ Modulation of gut microflora has been suggested as a safe and promising treatment in HIV infection. ${ }^{117-119}$

Probiotics have been shown to have favorable effects on alcoholic liver disease in clinical and experimental animal research. ${ }^{50-52,119}$ L. rhamnosus Gorbach-Goldin is one of the most widely studied probiotic strains with many well-documented benefits on several GI conditions and diseases. ${ }^{105,120}$ A limited number of studies using probiotic supplementation have been conducted in HIV infection; ${ }^{103-105,121-123}$ they have shown that probiotics were safe and effective in reducing diarrhea, nausea, and stabilizing CD4+ T-cell numbers. ${ }^{124}$ L. rhamnosus Gorbach-Goldin also reduced the duration and severity of diarrhea and improved humoral immune responses. ${ }^{124,125}$ While most of these studies have been limited by a small number of study participants and/or short treatment duration, ${ }^{103-106}$ they support the notion that probiotics may provide benefits in HIV infection, especially among patients with chronic alcohol consumption.

\section{Summary}

In summary, the majority of the reviewed RCTs on nutritional supplementation in PLWH were conducted before ART was developed or initiated, underscoring the need for trials of nutritional supplementation that include PLWH who are receiving ART, to assist in the recuperation of the immune response, maintaining adequate immune activation, reduce inflammation, and reestablishing adequate microbiota, which may be impaired by the long-term exposure to HIV and its treatment.

The composition and doses of the formulas used prior and after ART were diverse, but there was a convergence of the investigators' judgment on using multivitamin formulas with a broader composition before ART was available or initiated. An essential objective of the nutritional supplementation of PLWH prior to their eligibility for ART was reversing 
nutritional deficiencies that were identified in previous observational studies and delaying immune failure to prevent secondary infections.

After the advent and initiation of ART, the objectives of supplementation shifted to prevent the conditions that are associated with the chronic exposure to ART and associated with the aging of survivors, such as increased oxidative stress and increased morbidity for liver, kidney, cardiovascular disease, and cancers, all major causes of non-HIV-related deaths in PLWH. ${ }^{126}$ Our review confirms that nutritional supplementation with micronutrients and probiotics is immune stimulatory in both RCTs with ART-naive patients and in small trials with patients on ART and controlled viral load.

\section{Conclusion}

The main aim in the treatment of PLWH is preserving and enhancing the function of the immune system and reducing or controlling viral load. Immune reconstitution, however, does not always follow controlled viral load. While ART is provided according to prescribed standards to diminish HIV replication, the objectives of nutritional interventions in conjunction with ART should be achieving immune recovery, minimizing ART-related oxidative stress, preserving GI integrity, and preventing bacterial translocation and malnutrition. The literature, however, is sparse on research suggesting or demonstrating how to achieve these objectives through supplementation.

Currently, as the global effort to curtail the HIV epidemic is primarily directed toward broadening access to ART for PLWH in developing countries, and HIV is becoming a chronically managed disease in developed countries, research on HIV and nutrition should strive to evaluate the role of nutritional supplementation as a complementary therapy to ART. Further studies are needed to concentrate on the development of optimal nutrient formulas that foster immune recovery, decrease the short- and long-term nutritional adverse effects of ART, decrease bacterial translocation and immune activation, and prevent malnutrition. Trials with single nutrients may elucidate the role of the individual nutrients in achieving these objectives and support the incorporation of these nutrients into more complex formulas.

In PLWH, malnutrition inflicts an added immunesuppressive burden on the already immune-compromised system. Therefore, developing interventions for the prevention of nutrient deficiencies, with or without receiving ART, is still critical. Nutritional treatments should be individualized according to the patient's stage in the disease continuum, the type of ART combination used, the patient's nutritional status such as undernutrition and obesity, environmental exposure to opportunistic infections, and specific socioeconomic surroundings. ${ }^{127}$ Around the world, PLWH constitute clusters of very diverse populations, surrounded by different socioeconomic conditions that affect their access to treatment and their nutritional status. Recommendations for nutritional programs for PLWH need to be designed having in consideration this diversity.

\section{Disclosure}

The authors report no conflicts of interest in this work.

\section{References}

1. World Health Organization [webpage on the Internet]. Nutrition Databases. Available from: http://www.who.int/nutrition/databases/en/. Accessed June 7, 2015.

2. Singhal N, Austin J. A clinical review of micronutrients in HIV infection. J Int Assoc Physicians AIDS Care (Chic). 2002;1(2): 63-75.

3. Baum MK, Etengoff K, Marlink R, et al. Energy intake and HIV disease progression in asymptomatic ARV-naïve HIV+ adults in Botswana. In: Experimental Biology 2008 FASEB Conference; April 5-9, 2008; San Diego, CA.

4. Beisel WR. AIDS. Chapter 32. In: Gershwin ME, German JB, Keen CL, editors. Nutrition and Immunology: Principles and Practices. Totowa, NJ: Humana Press; 2000:389-403.

5. Lake JE, Currier JS. Metabolic disease in HIV infection. Lancet Infect Dis. 2013;13(11):964-975.

6. Pandhi D, Ailawadi P. Initiation of antiretroviral therapy. Indian J Sex Transm Dis. 2014;35(1):1-11.

7. Teklemariam Z, Mitiku H, Mesfin F. Prevalence of anemia and nutritional status among HIV-positive children receiving antiretroviral therapy in Harar, eastern Ethiopa. HIV AIDS (Auckl). 2015;5(7):191-196.

8. Tomita A, Garrett N, Werner L, et al. Health-related quality of life dynamics of HIV-positive South African women up to ART initiation: evidence from the CAPRISA 002 acute infection cohort study. AIDS Behav. 2014;18(6):1114-1123.

9. Bestawros M, Chidumayo T, Blevins M, et al. Increased systemic inflammation is associated with cardiac and vascular dysfunction over the first 12 weeks of antiretroviral therapy among undernourished, HIV-infected adults in Southern Africa. J AIDS Clin Res. 2015;6(3):431.

10. Campa A, Yang Z, Lai S, et al. HIV-related wasting in HIV-infected drug users in the era of highly active antiretroviral therapy. Clin Infect Dis. 2005;41:1179-1185.

11. Baum MK, Rafie C, Lai S, et al. Coronary heart disease risk factors and metabolic syndrome in HIV-positive chronic drug users in Miami. Am J Infect Dis. 2006;2(3):173-179.

12. Gazzola L, Tincati C, Bellistrì GM, Monforte A, Marchetti G. The absence of CD4+ T cell count recovery despite receipt of virologically suppressive highly active antiretroviral therapy: clinical risk, immunological gaps, and therapeutic options. Clin Infect Dis. 2009;48(3):328-337.

13. Tan R, Westfall AO, Willig JH, et al. Clinical outcome of HIV-infected antiretroviral-naive patients with discordant immunologic and virologic responses to highly active antiretroviral therapy. J Acquir Immune Defic Syndr. 2008;47(5):553-558.

14. Lederman HM, Williams PL, Wu JW, et al. Incomplete immune reconstitution after initiation of highly active antiretroviral therapy in human immunodeficiency virus-infected patients with severe CD4+ cell depletion. J Infect Dis. 2003;188:1794-1803.

15. Aukrust $P$, Muller F. Glutathione redox disturbances in human immunodeficiency virus infection: immunologic and therapeutic consequences. Nutrition. 1999;15(2):165-166. 
16. Gerschenson M, Brinkman K. Mitochondrial dysfunction in AIDS and its treatment. Mitochondrion. 2004;4(5-6):763-777.

17. Brinkman K, ter Hofstede HJ, Burger DM, Smeitink JAM, Koopmans PP. Adverse effects of reverse transcriptase inhibitors: mitochondrial toxicity as common pathway. AIDS. 1998;12:1735-1744.

18. Maagaard A, Holberg-Petersen M, Kvittingen EA, Sandvik L, Bruun JN. Depletion of mitochondrial DNA copies/cell in peripheral blood mononuclear cells in HIV-1-infected treatment-naïve patients. HIV Med. 2006;7:53-58.

19. Wester CW, Okezie OA, Thomas AM, et al. Higher-than-expected rates of lactic acidosis: preliminary results from a large randomized clinical trial. J Acquir Immune Defic Syndr. 2007;46(3):318-322.

20. Bussmann H, Wester CW, Thomas A, et al. Response to zidovudine/ didanosine-containing combination antiretroviral therapy among HIV-1 subtype C-infected adults in Botswana: two-year outcomes from a randomized clinical trial. J Acquir Immune Defic Syndr. 2009;51(1):37-46.

21. Campa A, Hatsu I, Baum MK. Nutrition and HIV. Chapter 24, Table 24-2. In: Eleonor S, Joyce G, editors. Essentials of Nutrition and Diet Therapy. 11th ed. St Louise, MO: Elsevier; 2015:554-556.

22. Drain PK, Kupka R, Mugusi F, Fawzi WW. Micronutrients in HIVpositive persons receiving highly active antiretroviral therapy. $\mathrm{Am} \mathrm{J}$ Clin Nutr. 2007;85:333-345.

23. Kaiser J, Campa A, Ondercin J, Leoung G, Pless R, Baum MK. Micronutrient supplementation increases CD4 count in HIV-infected Individuals on HAART: a prospective, double-blinded, placebo-controlled trial. J Acquir Immune Defic Syndr. 2006;42(5):523-528.

24. Jiamton S, Pepin J, Suttent R, et al. A randomized trial of the impact of multiple micronutrient supplementation on mortality among HIV-infected individuals living in Bangkok. AIDS. 2003;17(17):2461-2469.

25. Fawzi WW, Msamanga GI, Spiegelman D, et al. A randomized trial of multivitamin supplements and HIV disease progression and mortality. N Engl J Med. 2004;351(1):23-32.

26. de la Asunción JG, del Olmo ML, Sastre J, et al. AZT treatment induces molecular and ultrastructural oxidative damage to muscle mitochondria. Prevention by antioxidant vitamins. J Clin Invest. 1998;102(1):4-9.

27. Lopez O, Bonnefont-Rousselot D, Edeas M, Emerit J, Bricaire F. Could antioxidant supplementation reduce antiretroviral therapyinduced chronic stable hyperlactatemia? Biomed Pharmacother. 2003;57(3-4):113-116.

28. Beach RS, Mantero-Atienza E, Shor-Posner G, et al. Specific nutrients abnormalities in asymptomatic HIV infection. AIDS 1992;6:701-708.

29. Baum MK. Role of micronutrients in HIV-infected intravenous drug users. J Acquir Immune Defic Syndr. 2000;25:S49-S52.

30. Baum MK, Shor-Posner G, Lu Y, et al. Micronutients and HIV disease progression. AIDS. 1995;9:1051-1056.

31. Campa A, Shor-Posner G, Indacochea F, et al. Mortality risk in selenium deficient HIV-positive children. J Acquir Immune Defic Syndr Hum Retrovirol. 1999;20:508-513.

32. Baum MK. Nutritional alterations in high-risk groups in relationship to HIV-1 disease progression. Nutrition. 1996;12(21):124-126.

33. Baum MK, Shor-Posner G, Zhang G, et al. HIV-1 infection in women is associated with severe nutritional deficiencies. J Acquir Immune Defic Syndr Hum Retrovirol. 1997;16:272-278.

34. Baum MK, Shor Posner G, Campa A. Zinc status in human immunodeficiency virus infection. J Nutr. 2000;130:1421S-1423S.

35. Shor-Posner G, Baum MK. Nutritional alterations in HIV-1 seropositive and seronegative drug users. Nutrition. 1996;12:555-556.

36. Tang AM, Graham NM, Kirby AJ, McCall LD, Willet WC, Saah AJ. Dietary micronutrient intake and risk of progression to acquired immunodeficiency syndrome (AIDS) in human immunodeficiency virus type 1 (HIV-1)-infected homosexual men. Am J Epidemiol. 1993;138(11):937-951.

37. Tang AM, Graham NM, Semba RD, Saah AJ. Association between serum vitamin $\mathrm{A}$ and $\mathrm{E}$ levels and HIV-1 disease progression. AIDS. 1997;11:613-620.
38. Semba RD, Tang AM. Micronutrients and the pathogenesis of human immunodeficiency virus infection. Br J Nutr. 1999;81:181-189.

39. Baum MK, Lai S, Sales S, Page JB, Campa A. Randomized controlled clinical trial of zinc supplementation to prevent immunological failure in HIV-positive adults. Clin Infect Dis. 2010;50(12):1653-1660.

40. Jones CY, Tang AM, Forrester JE, et al. Micronutrient levels and HIV disease status in HIV-infected patients on highly active antiretroviral therapy in the nutrition for healthy living cohort. JAcquir Immune Defic Syndr. 2006;43(4):475-482.

41. Hommes MJT, Romi FA, Endert E, Saierweomg JP. Resting energy expenditure and substrate oxidation in human immunodeficiency virus (HIV)-infected asymptomatic HIV: HIV affects host metabolism in the early asymptomatic stage. Am J Clin Nutr. 1991;54:311-315.

42. Brenchley JM, Price DA, Schacker TW, et al. Microbial translocation is a cause of systemic immune activation in chronic HIV-infection. Nat Med. 2006;12:1365-1371.

43. Paiardini M, Frank I, Pandrea I, Apetrei C, Silvestri G. Mucosal immune dysfunction in AIDS pathogenesis. AIDS Rev. 2008;20(1):36-46.

44. Mollace V, Salvemini D, Riley DP, et al. The contribution of oxidative stress in apoptosis of human-cultured astroglial cells induced by supernatants of HIV-1-infected macrophages. J Leukoc Biol. 2002;71(1):65-72.

45. Welsh FK, Farmery SM, MacLennan K, et al. Gut barrier function in malnourished patients. Gut. 1998;42:396-401.

46. Reynolds JV, O'Farrelly C, Feighery C, et al. Impaired gut barrier function in malnourished patients. Br J Surg. 1996;83:1288-1291.

47. Al Anazi AR. Gastrointestinal opportunistic infections in human immunodeficiency virus disease. Saudi J Gastroenterol. 2009;15(2):95-99.

48. Vesterbacka J, Barqasho B, Häggblom A, Nowak P. Effects of cotrimoxazole on microbial translocation in HIV-1 infected patients initiating antiretroviral therapy. AIDS Res Hum Retroviruses. 2015; 31(8):830-836.

49. Jiang W, Lederman MM, Hunt $P$, et al. Plasma levels of bacterial DNA correlate with immune activation and the magnitude of immune restoration in persons with antiretroviral-treated HIV infection. J Infect Dis. 2009;199(8):1177-1185.

50. Nanji AA, Khettry U, Sadrzadeh SM. Lactobacillus feeding reduces endotoxemia and severity of experimental alcoholic liver (disease). Proc Soc Exp Biol Med. 1994;205:243-247.

51. Forsyth CB, Farhadi A, Jakate SM, Tang Y, Shaikh M, Keshavarzian A. Lactobacillus GG treatment ameliorates alcohol-induced intestinal oxidative stress, gut leakiness, and liver injury in a rat model of alcoholic steatohepatitis. Alcohol. 2009;43:163-172.

52. Kirpich IA, Solovieva NV, Leikhter SN, et al. Probiotics restore bowel flora and improve liver enzymes in human alcohol-induced liver injury: a pilot study. Alcohol. 2008;42:675-682.

53. Beach RS, Morgan R, Wilkie F, et al. Plasma vitamin $B_{12}$ level as a potential cofactor in studies of human immunodeficiency virus type-1 related cognitive changes. Arch Neurol. 1992;49:501-506.

54. Baum MK, Mantero-Atienza E, Shor-Posner G, et al. Association of vitamin $\mathrm{B}_{6}$ status with parameters of immune function in early HIV-1 infection. J Acquir Immune Defic Syndr. 1991;4:1122-1132.

55. Mehta S, Hunter DJ, Mugusi FM, et al. Perinatal outcomes, including mother-to-child transmission of HIV, and child mortality and their association with maternal vitamin D status in Tanzania. J Infect Dis. 2009;200(7):1022-1030.

56. Irlam JH, Visser ME, Rollins N, Siegfried N. Micronutrient supplementation in children and adults with HIV infection. Cochrane Database Syst Rev. 2005;(4):CD003650.

57. Kawai K, Kupka R, Mugusi F, et al. A randomized trial to determine the optimal dosage of multivitamin supplements to reduce adverse pregnancy outcomes among HIV-infected women in Tanzania. Am J Clin Nutr. 2010;91(2):391-397.

58. Kupka R, Mugusi F, Aboud S, Hertzmark E, Spiegelman D, Fawzi WW. Effect of selenium supplements on hemoglobin concentration and morbidity among HIV-1-infected Tanzanian women. Clin Infect Dis. 2009;48(10):1475-1478. 
59. Kupka R, Mugusi F, Aboud S, et al. Randomized, double-blind, placebocontrolled trial of selenium supplements among HIV-infected pregnant women in Tanzania: effects on maternal and child outcomes. Am J Clin Nutr. 2008;87(6):1802-1808.

60. Villamor E, Mugusi F, Urassa W, et al. A trial of the effect of micronutrient supplementation on treatment outcome, $\mathrm{T}$ cell counts, morbidity, and mortality in adults with pulmonary tuberculosis. $J$ Infect Dis. 2008;197(11):1499-1505.

61. Villamor E, Msamanga G, Saathoff E, Fataki M, Manji K, Fawzi WW. Effects of maternal vitamin supplements on malaria in children born to HIV-infected women. Am J Trop Med Hyg. 2007;76(6):1066-1071.

62. Fawzi WW, Msamanga GI, Kupka R, et al. Multivitamin supplementation improves hematologic status in HIV-infected women and their children in Tanzania. Am J Clin Nutr. 2007;85(5):1335-1343.

63. Smith Fawzi MC, Kaaya SF, Mbwambo J, et al. Multivitamin supplementation in HIV-positive pregnant women: impact on depression and quality of life in a resource-poor setting. HIV Med. 2007;8(4):203-212.

64. McGrath N, Bellinger D, Robins J, Msamanga GI, Tronick E, Fawzi WW. Effect of maternal multivitamin supplementation on the mental and psychomotor development of children who are born to HIV-1-infected mothers in Tanzania. Pediatrics. 2006;117(2):e216-e225.

65. Villamor E, Saathoff E, Manji K, Msamanga G, Hunter DJ, Fawzi WW. Vitamin supplements, socioeconomic status, and morbidity events as predictors of wasting in HIV-infected women from Tanzania. Am J Clin Nutr. 2005;82(4):857-865.

66. Range N, Changalucha J, Krarup H, Magnussen P, Andersen AB, Friis H. The effect of multi-vitamin/mineral supplementation on mortality during treatment of pulmonary tuberculosis: a randomised two-by-two factorial trial in Mwanza, Tanzania. Br J Nutr. 2006;95(4):762-770.

67. Hurwitz BE, Klaus JR, Llabre MM, et al. Suppression of human immunodeficiency virus type 1 viral load with selenium supplementation: a randomized controlled trial. Arch Intern Med. 2007;167(2):148-154.

68. McClelland RS, Baeten JM, Overbaugh J, et al. Micronutrient supplementation increases genital tract shedding of HIV-1 in women: results of a randomized trial. J Acquir Immune Defic Syndr. 2004;37(5):1657-1663.

69. Merchant AT, Msamanga G, Villamor E, et al. Multivitamin supplementation of HIV-positive women during pregnancy reduces hypertension. J Nutr. 2005;135(7):1776-1781.

70. Baylin A, Villamor E, Rifai N, Msamanga G, Fawzi WW. Effect of vitamin supplementation to HIV-infected pregnant women on the micronutrient status of their infants. Eur J Clin Nutr. 2005;59(8):960-968.

71. Villamor E, Saathoff E, Bosch RJ, et al. Vitamin supplementation of HIV-infected women improves postnatal child growth. Am J Clin Nutr. 2005;81(4):880-888.

72. Fawzi W. Micronutrients and human immunodeficiency virus type 1 disease progression among adults and children. Clin Infect Dis. 2003;37(suppl 2):S112-S116.

73. Friis H. Micronutrient interventions and HIV infection: a review of the literature. Trop Med Int Health. 2006;11(12):1849-1857.

74. Jacobus DP. Randomization to iron supplementation of patients with advanced human immunodeficiency virus disease - an inadvertent but controlled study with results important for patient care. J Infect Dis. 1996;153:1044-1045.

75. Villamor E, Aboud S, Koulinska IN, et al. Zinc supplementation to HIV1-infected pregnant women: effects on maternal anthropometry, viral load, and early mother-to-child transmission. Eur J Clin Nutr. 2006;60(7): 862-869.

76. Cárcamo C, Hooton T, Weiss NS, et al. Randomized controlled trial of zinc supplementation for persistent diarrhea in adults with HIV-1 infection. J Acquir Immune Defic Syndr. 2006;43(2): 197-201.

77. Allen LH, Peerson JM, Olney DK. Provision of multiple rather than two or fewer micronutrients more effectively improves growth and other outcomes in micronutrient-deficient children and adults. $J$ Nutr. 2009;139(5):1022-1030.

78. Academy of Nutrition and Dietetics [webpage on the Internet]. Evidence Analysis Manual. Available from: http://www.adaevidencelibrary.com/ category.cfm?cid=7\&cat=0. Accessed June 20, 2015.
79. Baum MK, Campa A, Lai S, et al. Effect of micronutrient supplementation on disease progression in asymptomatic, antiretroviral-naive, HIV-infected adults in Botswana: a randomized clinical trial. JAMA. 2013;310(20):2154-2163.

80. Villamor E, Msamanga G, Spiegelman D, et al. Effect of multivitamin and vitamin A supplements on weight gain during pregnancy among HIV-1-infected women. Am J Clin Nutr. 2002;76(5):1082-1090.

81. Fawzi WW, Msamanga GI, Hunter D, et al. Randomized trial of vitamin supplements in relation to transmission of HIV-1 through breastfeeding and early child mortality. AIDS. 2002;16(14):1935-1944.

82. Sudfeld CR, Aboud S, Kupka R, Mugusi FM, Fawzi WW. Effect of selenium supplementation on HIV-1 RNA detection in breast milk of Tanzanian women. Nutrition. 2014;30(9):1081-1084.

83. Webb AL, Aboud S, Furtado J, et al. Effect of vitamin supplementation on breast milk concentrations of retinol, carotenoids and tocopherols in HIV-infected Tanzanian women. Eur J Clin Nutr. 2009;63(3):332-339.

84. Arsenault JE, Aboud S, Manji KP, Fawzi WW, Villamor E. Vitamin supplementation increases risk of subclinical mastitis in HIV-infected women. J Nutr. 2010;140(10):1788-1792.

85. Villamor E, Koulinska IN, Aboud S, et al. Effect of vitamin supplements on HIV shedding in breastmilk. Am J Clin Nutr. 2010;92(4):881-886.

86. Austin J, Singhal N, Voigt R, et al. A community randomized controlled clinical trial of mixed carotenoids and micronutrient supplementation of patients with acquired immunodeficiency syndrome. Eur J Clin Nutr. 2006;60(11):1266-1276.

87. Isanaka S, Mugusi F, Hawkins C, et al. Effect of high-dose vs standarddose multivitamin supplementation at the initiation of HAART on HIV disease progression and mortality in Tanzania: a randomized controlled trial. JAMA. 2012;308(15):1535-1544.

88. Arpadi SM, McMahon D, Abrams EJ, et al. Effect of bimonthly supplementation with oral cholecalciferol on serum 25-hydroxyvitamin D concentrations in HIV-infected children and adolescents. Pediatrics. 2009;123(1):e121-e126.

89. Longenecker CT, Hileman CO, Carman TL, et al. Vitamin D supplementation and endothelial function in vitamin D deficient HIVinfected patients: a randomized placebo-controlled trial. Antivir Ther. 2012;17(4):613-621.

90. Kakalia S, Sochett EB, Stephens D, Assor E, Read SE, Bitnun A. Vitamin D supplementation and CD4 count in children infected with human immunodeficiency virus. J Pediatr. 2011;159(6):951-957.

91. Guaraldi G, Ventura P, Albuzza M, et al. Pathological fractures in AIDS patients with osteopenia and osteoporosis induced by antiretroviral therapy. AIDS. 2001;15:137-138.

92. Huang JS, Rietschel P, Hadigan CM, Rosenthal DI, Greenspoon S. Increased abdominal visceral fat is associated with reduced bone density in HIV-infected men with lipodystrophy. AIDS. 2001;15:975-982.

93. Badiou S, De Boever CM, Terrier N, Baillat V, Cristol JP, Reynes J. Is tenofovir involved in hypophosphatemia and decrease of tubular phosphate reabsorption in HIV-positive adults? J Infect. 2006;52(5): 335-338.

94. Gafni RI, Hazra R, Reynolds JC, et al. Tenofovir disoproxil fumarate and an optimized background regimen of antiretroviral agents as salvage therapy: impact on bone mineral density in HIV-infected children. Pediatrics. 2006;118(3):e711-e718.

95. Carr A, Miller J, Eisman JA, Copper DA. Osteopenia in HIV-infected men: association with asymptomatic lactic acidemia and lower weight pre-antiretroviral therapy. AIDS. 2001;15:703-709.

96. Serrano S, Mariñoso ML, Soriano JC, et al. Bone remodeling in human immunodeficiency virus-1-infected patients: a histomorphometric study. Bone. 1995;16:185-191.

97. Dietary Reference Intake Tables [homepage on the Internet]. The Complete Set. Institute of Medicine, National Academy of Sciences. Available from: www.nap.edu. Accessed March 27, 2015.

98. Kumwenda N, Miotti PG, Taha TE, et al. Antenatal vitamin A supplementation increases birth weight and decreases anemia among infants born to human immunodeficiency virus-infected women in Malawi. Clin Infect Dis. 2002;35(5):618-624. 
99. Mda S, van Raaij JM, de Villiers FP, Kok FJ. Impact of multi-micronutrient supplementation on growth and morbidity of HIV-infected South African children. Nutrients. 2013;5(10):4079-4092.

100. Bobat R, Coovadia H, Stephen C, et al. Safety and efficacy of zinc supplementation for children with HIV-1 infection in South Africa: a randomized double-blind placebo-controlled trial. Lancet. 2005;336:1862-1867.

101. Marks DJ, Dheda K, Dawson R, Ainslie G, Miller R F. Adverse sensory polyneuropathy in HIV-TB, 33 events to antituberculosis therapy: influence of HIV and antiretroviral drugs. Int J STD AIDS. 2009;20:339-345.

102. Asdamongkol N, Phanachet P, Sungkanuparph S. Low plasma zinc levels and immunological responses to zinc supplementation in HIVinfected patients with immunological discordance after antiretroviral therapy. Jpn J Infect Dis. 2013;66(6):469-474.

103. Hummelen R, Hemsworth J, Changalucha J, et al. Effect of micronutrient and probiotic fortified yogurt on immune-function of anti-retroviral therapy naive HIV patients. Nutrients. 2011;3(10):897-909.

104. Hummelen R, Changalucha J, Butamanya NL, Cook A, Habbema JD, Reid G. Lactobacillus rhamnosus GR-1 and L. reuteri RC-14 to prevent or cure bacterial vaginosis among women with HIV. Int J Gynaecol Obstet. 2010;111(3):245-248.

105. Van Niekerk E, Kirsten GF, Nel DG, Blaauw R. Probiotics, feeding tolerance, and growth: a comparison between HIV-exposed and unexposed very low birth weight infants. Nutrition. 2014;30(6):645-653.

106. Villar-García J, Hernández JJ, Güerri-Fernández R, et al. Effect of probiotics (Saccharomyces boulardii) on microbial translocation and inflammation in HIV-treated patients: a double-blind, randomized, placebo-controlled trial. J Acquir Immune Defic Syndr. 2015;68(3):256-263.

107. Shey WI, Brocklehurst P, Sterne JA. Vitamin A supplementation for reducing the risk of mother-to-child transmission of HIV infection. Cochrane Database Syst Rev. 2002;(3):CD003648.

108. Cunningham-Rundles S, Ahrné S, Johann-Liang R, et al. Effect of probiotic bacteria on microbial host defense, growth, and immune function in human immunodeficiency virus type-1 infection. Nutrients. 2011;3(12):1042-1070.

109. Hummelen R, Vos AP, van't Land B, van Norren K, Reid G. Altered host-microbe interaction in HIV: a target for intervention with pro- and prebiotics. Int Rev Immunol. 2010;29(5):485-513.

110. Estes JD, Harris LD, Klatt NR, et al. Damaged intestinal epithelial integrity linked to microbial translocation in pathogenic simian immunodeficiency virus infections. PLoS Pathog. 2010;6(8):e1001052.

111. Ancuta P, Kamat A, Kunstman KJ, et al. Microbial translocation is associated with increased monocyte activation and dementia in AIDS patients. PLoS One. 2008;3(6):e2516.

112. Schneider T, Jahn HU, Schmidt W, Riecken EO, Zeitz M, Ullrich R. Loss of CD4 $\mathrm{T}$ lymphocytes in patients infected with human immunodeficiency virus type 1 is more pronounced in the duodenal mucosa than in the peripheral blood. Berlin Diarrhea/Wasting Syndrome Study Group. Gut. 1995;37:524-529.
113. Mehandru S, Poles MA, Tenner-Racz K, et al. Primary HIV-1 infection is associated with preferential depletion of CD4+ T lymphocytes from effector sites in the gastrointestinal tract. J Exp Med. 2004;200:761-770.

114. Nazli A, Chan O, Dobson-Belaire WN, et al. Exposure to HIV-1 directly impairs mucosal epithelial barrier integrity allowing microbial translocation. PLoS Pathog. 2010;6:e1000852.

115. Brenchley JM, Paiardini M, Knox KS, et al. Differential Th17 CD4 T-cell depletion in pathogenic and nonpathogenic lentiviral infections. Blood. 2008;112:2826-2835.

116. Gori A, Tincati C, Rizzardini G, et al. Early impairment of gut function and gut flora supporting a role for alteration of gastrointestinal mucosa in human immunodeficiency virus pathogenesis. J Clin Microbiol. 2008;46(2):757-758

117. Ipp H, Zemlin AE, Erasmus RT, Glashoff RH. Role of inflammation in HIV-1 disease progression and prognosis. Crit Rev Clin Lab Sci. 2014;51(2):98-111.

118. Wang HJ, Gao B, Zakhari S, Nagy LE. Inflammation in alcoholic liver disease. Annu Rev Nutr. 2012;32:343-368.

119. Wang Y, Kirpich I, Liu Y, et al. Lactobacillus rhamnosus GG treatment potentiates intestinal hypoxia-inducible factor, promotes intestinal integrity and ameliorates alcohol-induced liver injury. Am J Pathol. 2011;179:2866-2875.

120. Segers ME, Lebeer S. Towards a better understanding of Lactobacillus rhamnosus GG-host interactions. Microb Cell Fact. 2014; 13(suppl 1):S7.

121. Anukam KC, Osazuwa EO, Osadolor HB, Bruce AW, Reid G. Yogurt containing probiotic Lactobacillus rhamnosus GR-1 and L. reuteri RC-14 helps resolve moderate diarrhea and increases CD4 count in HIV/AIDS patients. J Clin Gastroenterol. 2008;42(3):239-243.

122. Kerac M, Bunn J, Seal A, et al. Probiotics and prebiotics for severe acute malnutrition (PRONUT study): a double-blind efficacy randomised controlled trial in Malawi. Lancet. 2009;374(9684):136-144.

123. Yang OO, Kelesidis T, Cordova R, et al. Immunomodulation of antiretroviral drug-suppressed chronic HIV-1 infection in an oral probiotic double-blind placebo-controlled trial. AIDS Res Hum Retroviruses. 2014;30(10):988-995.

124. Miettinen M, Vuopio-Varkila J, Varkila K. Production of human tumor necrosis factor alpha, interleukin-6, and interleukin-10 is induced by lactic acid bacteria. Infect Immun. 1996;64(12):5403-5405.

125. Guarino A, Canani RB, Spagnuolo MI, Albano F, Di Benedetto L. Oral bacterial therapy reduces the duration of symptoms and of viral excretion in children with mild diarrhea. J Pediatr Gastroenterol Nutr. 1997;25:516-519.

126. Smith CJ, Ryom L, Weber R, et al. Trends in underlying causes of death in people with HIV from 1999 to 2011 (D:A:D): a multicohort collaboration. Lancet. 2014;384(9939):241-248.

127. Fields-Gardner C, Campa A; American Dietetic Association. Position of the American Dietetic Association: nutrition intervention and human immunodeficiency virus infection. J Am Diet Assoc. 2010;110(7):1105-1119.
Nutrition and Dietary Supplements

\section{Publish your work in this journal}

Nutrition and Dietary Supplements is an international, peer-reviewed, open access journal focusing on research into nutritional requirements in health and disease, impact on metabolism and the identification and optimal use of dietary strategies and supplements necessary for normal growth and development. The journal welcomes papers covering

\section{Dovepress}

original research, basic science, clinical \& epidemiological studies, reviews and evaluations, guidelines, expert opinion and commentary, case reports and extended reports. The manuscript management system is completely online and includes a very quick and fair peer-review system, which is all easy to use. 